\title{
Program Kemitraan Masyarakat Stimulus (PKMS) Usaha Mikro Kecil Menengah (UMKM) Qiyara Batik
}

\author{
Anton Respati Pamungkas ${ }^{1}$, Paryanta ${ }^{2}$ \\ ${ }^{1}$ STMIK AUB Surakarta, ${ }^{2}$ STMIK AUB Surakarta \\ e-mail: ${ }^{1}$ anton18@stmik-aub.ac.id, ${ }^{2}$ paryanta@ stmik-aub.ac.id
}

\begin{abstract}
Abstrak
UMKM berperanan penting bagi perekonomian di Negara kita yang tumbuh dan berkembang daerah UMKM berperanan penting bagi perekonomian di Negara kita yang tumbuh dan berkembang daerah perkotaan maupun pedesaan. Namun UMKM saat ini banyak yang mengalami masalah terutama dari segi manajemen dan pemasaran karena sebagian besar pemilik UMKM tingkat pendidikan masih rendah. Dari segi pemasaran hasil penjualan belum memenuhi target, hal ini dikarenakan sistem promosi belum memanfaat teknologi informasi yang berkembang saat ini. Berdasarkan data penjualan yang diperoleh dari UMKM Qiyara Batik menunjukkan penurunan dikarenakan dampak dari pandemi covid19 yang hingga saat ini belum selesai. Masalah lain yang dihadapi UMKM Qiyara Batik lemahnya manajemen dan sistem pemasaran selama ini masih menggunakan Whatsapp, gethok tular dari teman ke teman jadi belum memanfaatkan teknologi informasi saat ini seperti marketplace, fanspage, instagram dan website. permasalahan yang lain tidak tertibnya pencatatan transaksi penjualan belum adanya laporan keuangan yang baik sehingga tidak bisa diketahui dengan jelas pendapatan tiap harinya.
\end{abstract}

Untuk mengatasi permasalahan yang dihadapi UMKM Qiyara Batik, yaitu dengan cara merubah mainset yaitu strategi pemasaran memanfaatkan Teknologi Informasi dan Komunikasi melalui pelatihan strategi pemasaran, penggunaan media sosial dan marketplace.

Dengan terlaksananya kegiatan PKMS ini mitra dapat mengetahui tentang strategi pemasaran digital sehingga usahanya semakin berkembang dan dapat menciptakan usaha lapangan kerja baru.

Kata kunci: UMKM, Qiyara, Batik, Pemasaran, Teknologi, Informasi, Komunikasi

\section{PENDAHULUAN}

UMKM mempunyai peranan penting dalam petumbuhan perekonomian di Indonesia terutama di daerah perkotaan maupun pedesaan. Disamping itu UMKM dapat menciptakan lapangan pekerjaan baru sehingga dapat membantu menggerakkan perekonomian di daerah, akan tetapi UMKM saat masih menghadapi berbagai masalah mendasar, yaitu masalah manajemen sumber daya, kualitas hasil produk, sistem pemasaran dan administrasi. Dalam krisis ekonomi yang terjadi di negara kita sejak adanya pandemi virus covid-19 ini, dimana banyak usaha berskala besar yang mengalami pengurangan karyawan bahkan berhenti dari kegiatan produksi. Sektor UMKM juga ikut terdampak dengan mewabahnya virus covid-19 yang sampai saat ini juga belum usai.

Mengutip dari DDTCNews-Pemerintah mengidentifikasi empat permasalahan utama yang dihadapi pelaku usaha mikro, kecil dan menengah (UMKM) pada masa pandemi Covid-19 saat ini. Deputi Bidang Produksi dan Pemasaran Kementerian Koperasi dan UMKM (Kemenkop) Victoria Simanungkalit mengatakan empat persoalan itu antara lain penurunan permintaan, pemasaran produk, akses bahan baku dan masih rendahnya SDM.[1]

Dari hasil wawancaran yang dilakukan pada tanggal 6 Oktober 2020 dengan dengan Ibu Nurul Arifah pengrajin batik yang beralamat Madumulyo RT 7 RW 1 Pulisen Boyolali, beliau menyampaikan bahwa usaha yang dilakukan saat ini mengalami penurunan omzet penjualan karena dampak dari pandemic covid-19.

Usaha yang dimiliki oleh ibu Nurul Arifah yang diberi nama Qiyara Batik saat ini memiliki 3 karyawan, modal usaha sebesar Rp. 7.000.000,- dengan jenis usaha memproduksi dan memasarkan seperti kain batik sibhori, kain batik jumputan, kain batik tulis. Hasil produksi yang dipasarkan dapat dilihat pada gambar 1. 


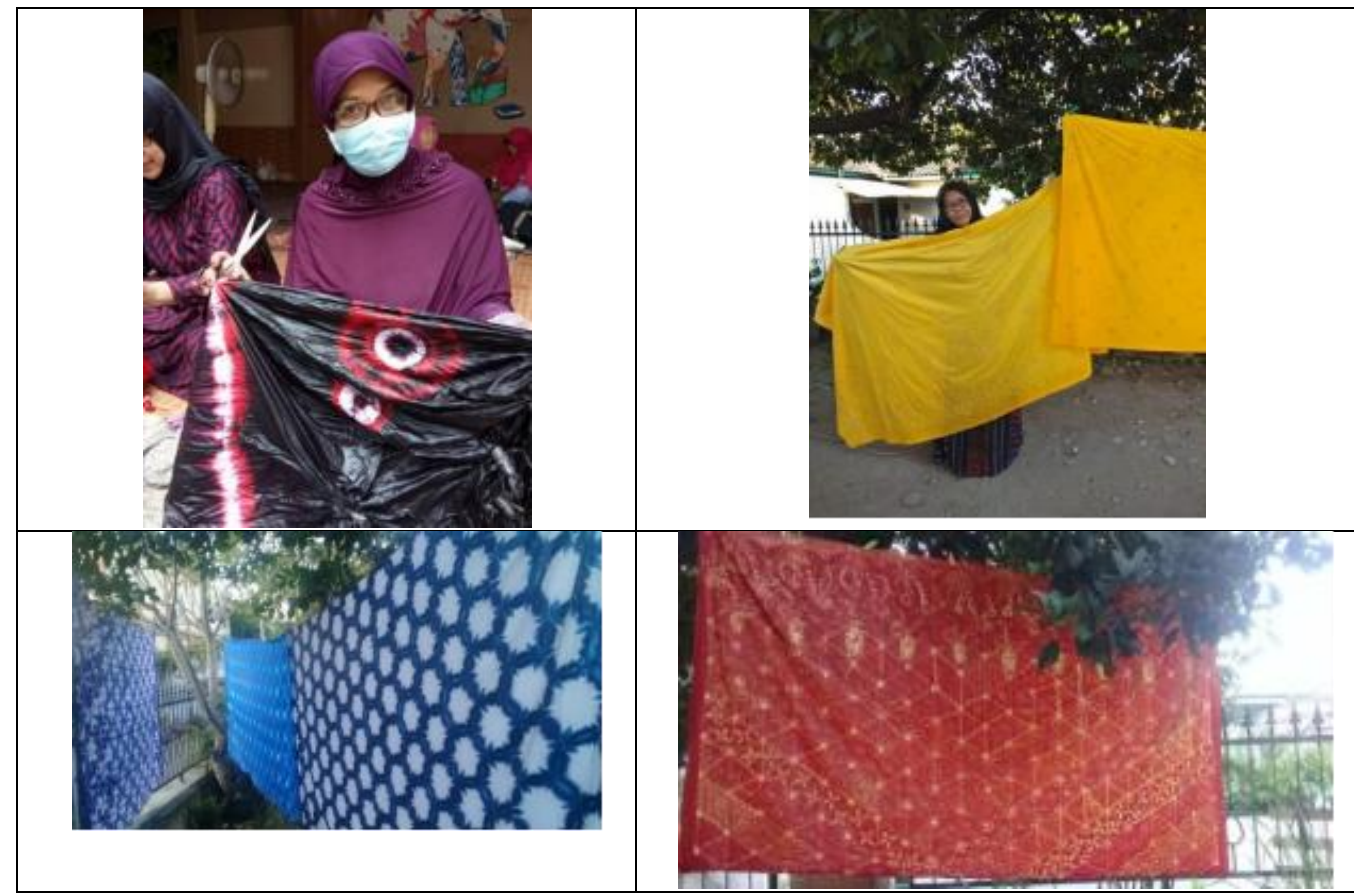

Gambar 1. 1 Kegiatan membatik dan hasilnya

Sistem produksi UMKM Qiyara Batik dilakukan ketika ada pesanan saja sesuai sesuai dengan permintaan konsumen. Jadi ketika ada pesan kain batik saat itu juga dibuatkan sesuai motif batik yang diminta konsumen pada waktu melakukan penawaran yang telah dikirimkan ke konsumen. Melalui sistem ini sehingga memerlukan waktu dalam penyelesaian pembuatan produk batik dipesan.

Saat ini pengrajin mengandalkan pemasarannya melalui cara gethok tular atau dari mulut ke mulut konsumen serta dengan cara door to door, melalui WA, mengikuti pameran yang diselenggarakan dinas internal terkait. Jadi dapat disimpulkan bahwa pemasaran belum optimal pengrajin masih gaptek, apalagi sejak dengan adanya pendemi covid-19 pesanan menurun drastis. Pencatatan transaksi penjualan masih dilakukan secara manual yaitu ditulis dalam buku pesanan dan penjualan, belum ada catatan transaksi penjualan maupun laporan yang sistematis sehingga belum bisa diketahui pendapatan yang pasti. Data penjualan yang didapatkan dari hasil wawancara dapat dilihat pada tabel 1

Tabel 1 Data Omzet Penjualan Batik tahun 2020

\begin{tabular}{|c|c|c|c|c|c|c|c|c|c|}
\hline Nama Produk & \multicolumn{10}{|c|}{ Bulan } \\
\cline { 2 - 11 } & Jan & Feb & Mar & April & Mei & Juni & Juli & Agst & Sep \\
\hline Batik sibhori & 20 & 30 & 10 & 10 & 32 & 18 & 16 & 17 & 18 \\
\hline Batik jumputan & 25 & 27 & 8 & 7 & 28 & 14 & 11 & 12 & 15 \\
\hline Batik tulis & 3 & 4 & 0 & 0 & 2 & 1 & 0 & 1 & 1 \\
\hline
\end{tabular}

Berdasarkan tabel 1 diatas yang diperoleh dari pengrajin Batik terlihat bahwa penjualan tahun 2020 mulai bulan Januari sampai dengan Bulan September terus mengalami penurunan, salah satu sebabnya adalah adanya wabah pandemi Covid- 19 pemerintah memberlakukan kebijakan PSBB dengan pemberlakukan protokol kesehatan yang sampai saat ini belum juga usai, sehingga orang akan melakukan pemesanan secara langsung mengalami ketakutan. Pada Bulan Januari Batik Sibori terjual 20 lembar kain, Batik Jumputan terjual 25 lembar kain, Batik Tulis 3 lembar kain. Kemudian pada bulan September Batik Sibori terjual 18 lembar kain, Batik Jumputan terjual 15 lembar kain, Batik Tulis 1 lembar kain. Satu lembar kain berukuran 2x1 meter.

\section{METODE PENGABDIAN}

Tahapan Pelaksanaan Pelatihan kepada mitra tentang strategi pemasaran digital marketing

Pelaksanaan pelatihan tentang strategi pemasaran digital marketing menggunakan (Fanspage, 
Instagram, Marketplace) kepada mitra dilakukan melalui tahapan sebagai berikut:

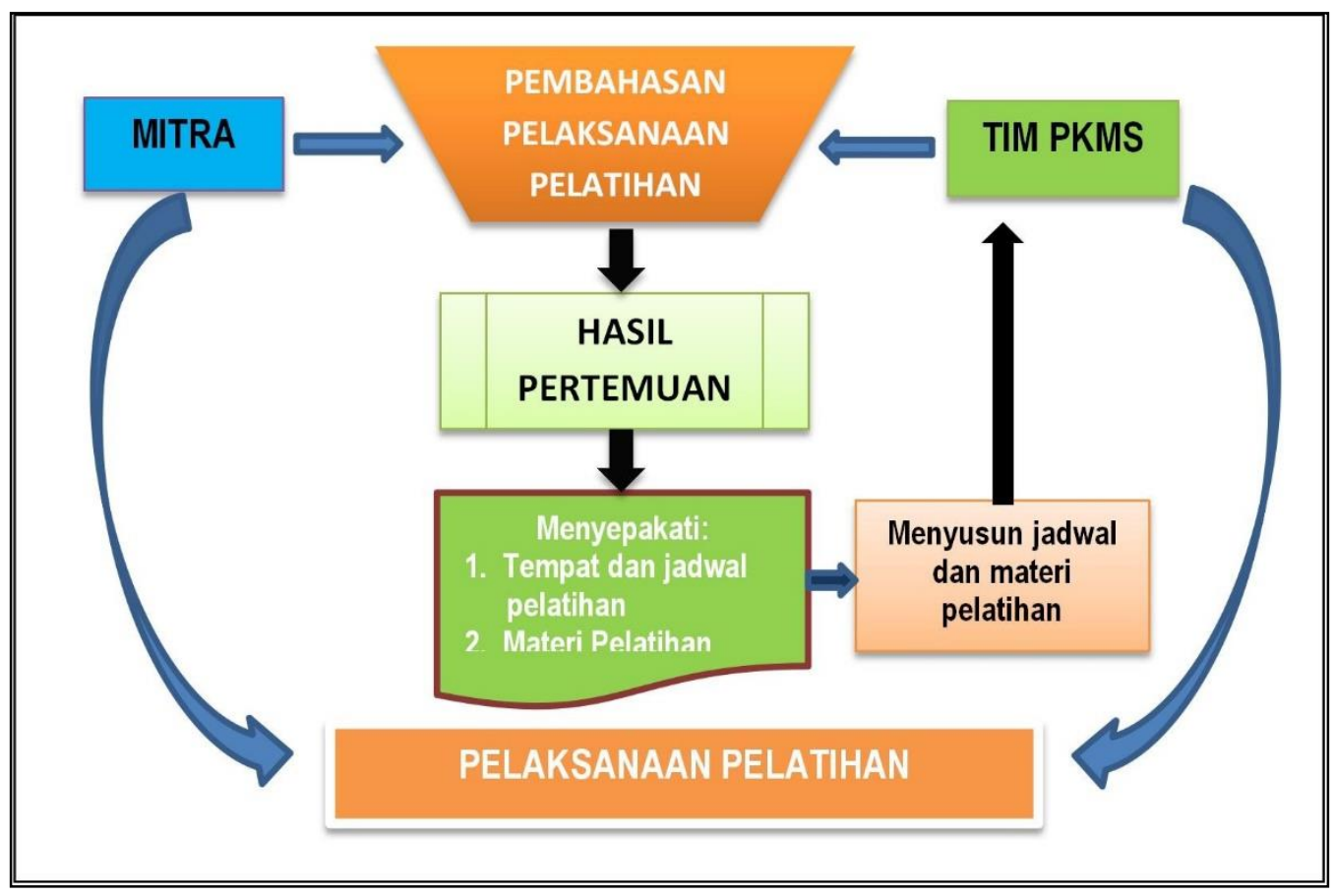

Gambar 2.1 Metode Pelaksanaan Pelatihan kepada mitra

Penjelasan tahapan pelaksanaan pelatihan kepada mitra tentang strategi pemasaran sebagai berikut: Tim PKM mengadakan pertemuan dengan mitra untuk membahas tentang solusi yang telah disepakati yaitu:

a. Waktu pelaksanaan pelatihan diselenggarakan pada tanggal 30 Juli sampai dengan 31 Agustus 2021, mulai jam 8.00 sampai dengan jam 16.00 .

b. Tempat pelaksanaan Madumulyo RT 7 RW 1 Pulisen Boyolali

c. Materi pelatihan sebagai berikut:

1) Menjelaskan konsep Pemasaran Online

$\checkmark$ Pengertian Pemasaran Online

$\checkmark$ Manfaat Pemasaran Online

$\checkmark$ Komponen Pemasaran Online

$\checkmark$ Cara kerja Pemasaran Online

2) Memahami Pemasaran Online dengan menggunakan E-mail

$\checkmark$ Pengertian E-mail

$\checkmark$ Membuat E-mail

$\checkmark$ Menulis E-mail dengan format website

3) Pemasaran Online dengan menggunakan / memanfaatkan Media Sosial.

$\checkmark$ Pengertian media sosial

$\checkmark$ Penjelasan Perbedaan antara website biasa dengan media sosial untuk media promosi

$\checkmark$ Macam-macam pemasaran melalui media sosial (facebook, Instagram)

$\checkmark$ Membuat Fanspage pada facebook untuk pemasaran online produk UMKM

$\checkmark$ Membuat toko online di marketplace shopee, tokopedia, bukalapak, lazada untuk produk UMKM

$\checkmark$ Membuat instagram bagi UMKM dengan memasukan produknya guna dipasarkan online melalui media sosial instagram

$\checkmark$ Posting produk dan konten di akun instagram

4) Memahami cara pembuatan website promosi dengan baik dan benar

$\checkmark$ Merencanakan template website

$\checkmark$ Membuat dan Membedakan website statis dan dinamis 
$\checkmark$ Mengisi Produk ke dalam website

$\checkmark$ Membuat tampilan website lebih bagus dan profesional

$\checkmark$ Mengelola website untuk terus update untuk jangka panjang

Tahapan Pembuatan Sistem Informasi Penjualan Qiyara batik

Tahapan pembuatan sistem ini menggunakan metode Waterfall, yang merupakan proses aktivitas dasar yang terdiri dari spesifikasi, pengembangan, validasi dan evaluasi yang direpresentasikan dengan tahapan fase terpisah seperti spesifikasi kebutuhan, software design, implementasi, testing dan lainnya.

Prinsip dari penggunaan waterfall model yaitu semua proses aktivitas untuk melakukan perancangan software harus dilakukan perencanaan dan penjadwalan pada awal proses. Didalam waterfall model terdapat lima tahapan yang mana setiap tahapan berhubungan secara berurutan dan memberikan informasi yang diperlukan pada tahap berikutnya, setiap tahapan harus diselesaikan dahulu sebelum masuk ke tahap berikutnya. (Sommerville, 2011). [2]

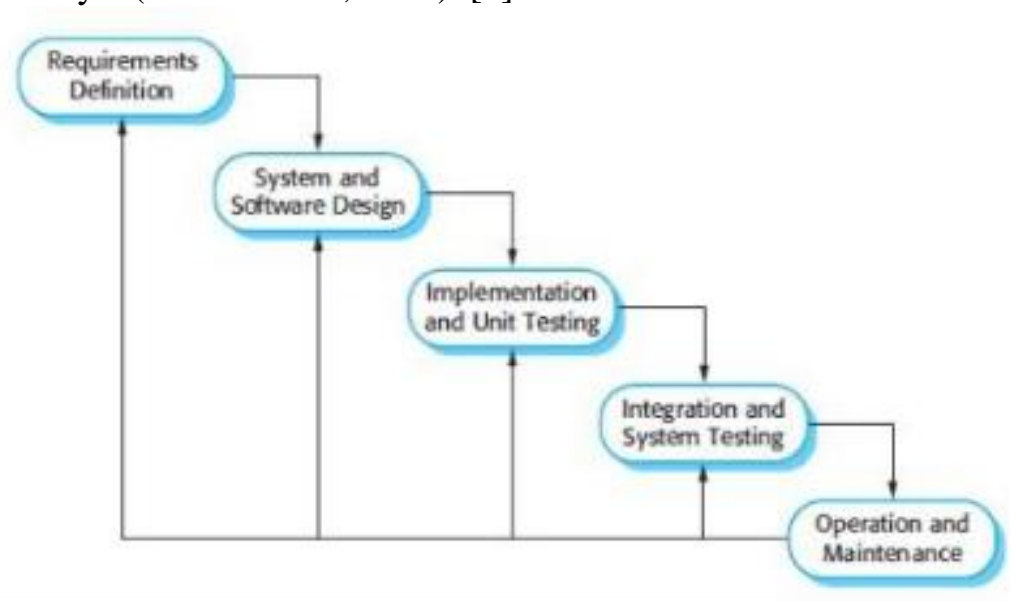

Gambar 2.2 Tahapan Pembuatan Sistem Informasi Penjualan Qiyara Batik

Berikut penjelasan dari tahap-tahap yang dilakukan di dalam metode ini :

a Requirements definition. Pada tahapan ini tim PKMS melakukan wawancara dengan mitra terkait dengan proses kegiatan mulai dari transaksi pemesanan barang sampai pembuatan laporan, mengumpulkan dokumen-dokumen yang dibutuhkan dalam pembuatan sistem. Hasil dari wawancara dan pengumpulan dokumen kemudian dilakukan analisa kebutuhan sistem. Penggambaran dalam analisa sistem menggunakan flowchart diagram,

Usecase Diagram, Activity Diagram, Sequence Diagram, Class Diagram

b. System And Software Design. Berdasarkan hasil analisa sistem tahapan selanjutnya proses perancangan sistem yaitu menterjemahkan syarat kebutuhan sistem kedalam perancangan perangkat lunak agar dapat dibuat coding.

c. Implementation And Unit Testing. Pada tahapan ini merupakan kegiatan menterjemahkan hasil perancangan sistem ke dalam Bahasa Pemrograman komputer. Bahasa pemrograman yang digunakan HTML, PHP, java, dan database menggunakan MySQL.

d. Integration And Sytem Testing. Setelah sistem selesai dibuat tahapan selanjutnya dilakukan uji coba sistem (testing) yang telah dibuat. Tujuan testing adalah menemukan kesalahan-kesalahan terhadap sistem tersebut dan kemudian bisa diperbaiki. Pengujian sistem mengunakan metode black box testing.

e. Operation And Maintenance. Setelah dilakukan pengujian sistem Tahapan berikutnya sistem bisa diimplementasikan dan dilakukan perawatan terhadap sistem tersebut. Pada tahapan ini juga dilakukan pelatihan terhadap mitra tentang bagaimana mengoperasikan sistem tersebut. 


\section{HASIL DAN PEMBAHASAN}

Pelaksanaan Pelatihan

Setelah dilaksanakan pelatihan digital marketing pada pemilik UMKM Qiyara Batik yang awalnya hanya memahami Facebook yang dimanfaatkan hanya sebagai media sosial serta belum mengenal tentang marketplace, saat ini media sosial tersebut telah dimanfaatkan sebagai promosi dan sekaligus transaksi jual beli secara online.

Pada gambar 3.1 menunjukkan bahwa tingkat pemahaman pemilik UMKM Qiyara Batik tentang dunia dibidang marketplace sangat rendah sekali.

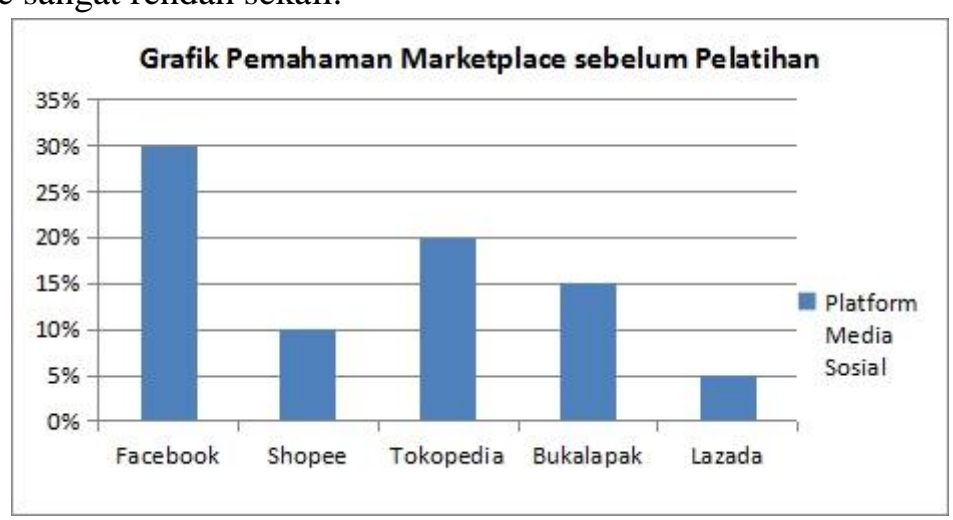

Gambar 3. 1 Pemahaman tentang marketplace sebelum pelatihan

Pada gambar 3.2 menunjukkan tingkat pemahaman pemilik UMKM Qiyara Batik tentang dunia dibidang marketplace sudah baik.

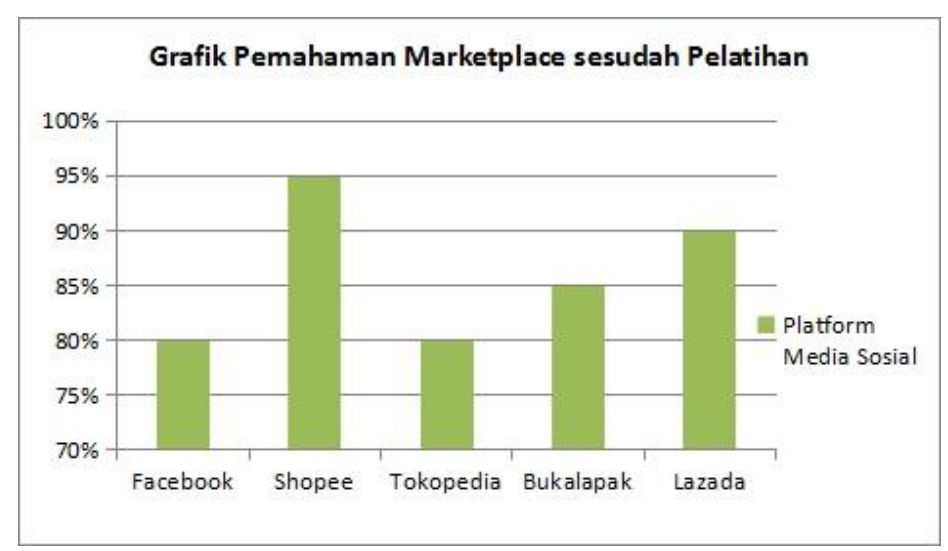

Gambar 3. 2 Pemahaman Marketplace sesudah Pelatihan

Pada gambar 3.3 menunjukkan bahwa pengelolaan sistem administrasi pemesanan penjulan sampai dengan pencatatan administrasi pembukuan dalam menyusun laporan masih sangat rendah.

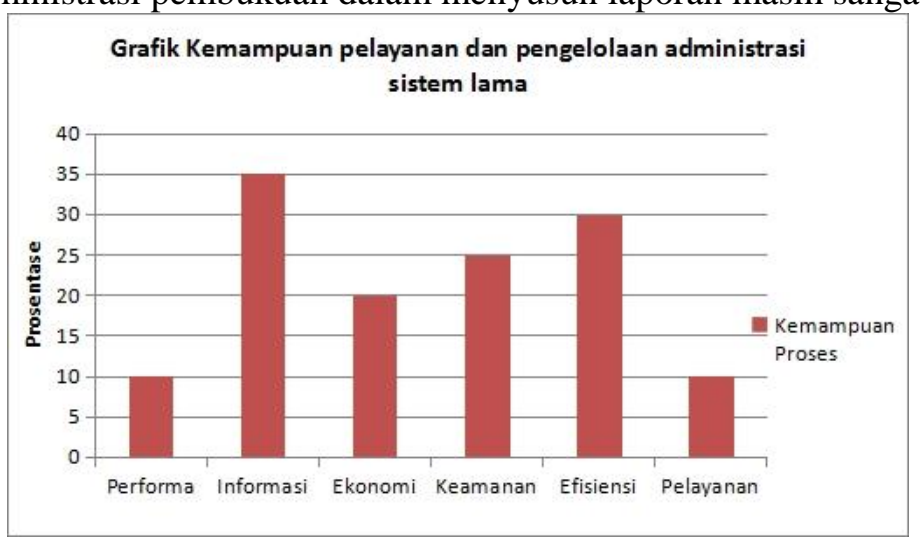

Gambar 3. 3 Kemampuan pelayanan dan pengelolaan administrasi sistem lama 
Pada gambar 3.4 menunjukkan bahwa pengelolaan sistem administrasi pemesanan penjulan sampai dengan pencatatan administrasi pembukuan dalam menyusun laporan masih sangat baik.

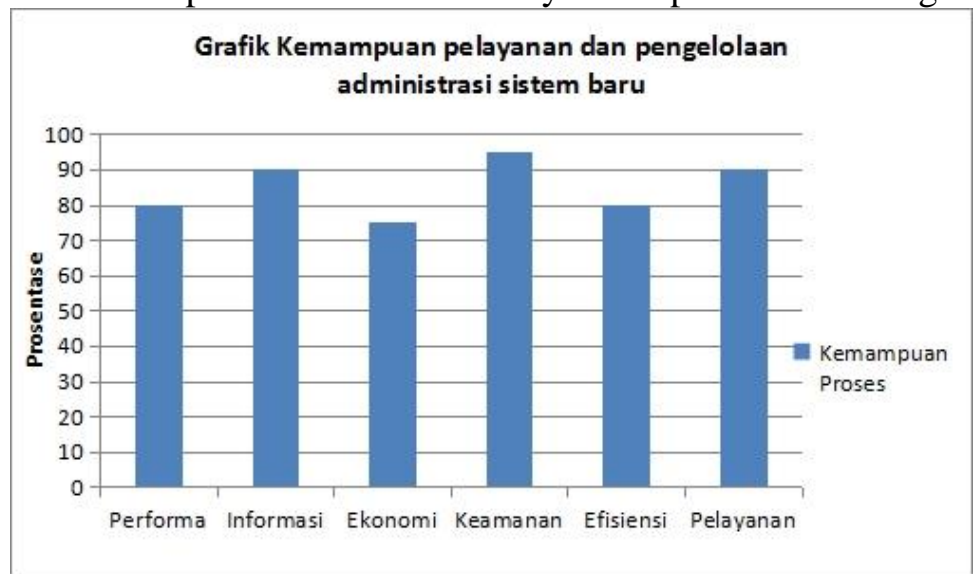

Gambar 3. 4 Kemampuan pelayanan dan pengelolaan administrasi sistem baru

Kegiatan pengabdian kepada masyarakat melalui PKMS ini, dalam pelaksanaannya memberikan pelatihan mengenai strategi pemasaran secara online, setelah diberikan pelatihan mitra tidak langsung dilepaskan begitu saja karena perlu pendampingan. Telah disepakati bahwa setelah program ini selesai mitra diberikan pendampingan selama dua bulan, kemudian secara berkala tim PKMS akan memberikan informasi mengenai perkembangan teknologi informasi yang baru mengingat perkembangannya yang begitu cepat, kalau memang diperlukan pelatihan tim siap memberikan pelatihan.

Selain memberikan pendampingan terkait strategi pemasaran online, juga diberikan pendampingan tentang tentang tata kelola manajemen usaha yang baik, pengelolaan sumber daya yang efektif, efisien dan produktifitas meningkat, sehingga akan menjamin keberlangsungan usaha ini. Disamping itu juga memberikan pendampingan mengelola administrasi pembukuan terkait biaya operasional, omzet penjualan sehingga dapat dilihat seberapa besar pendapatan bersih yang diterima.

3.2 Implentasi Sistem Informasi Penjualan

Sistem Informasi penjualan telah diimpelentasikan pada UMKM Qiyara Batik Boyolali dengan baik sehingga dapat membantu proses pemesanan sampai pencatatan dan pelaporannnya, yang dapat digambarkan sebagai berikut:

a. Form Login

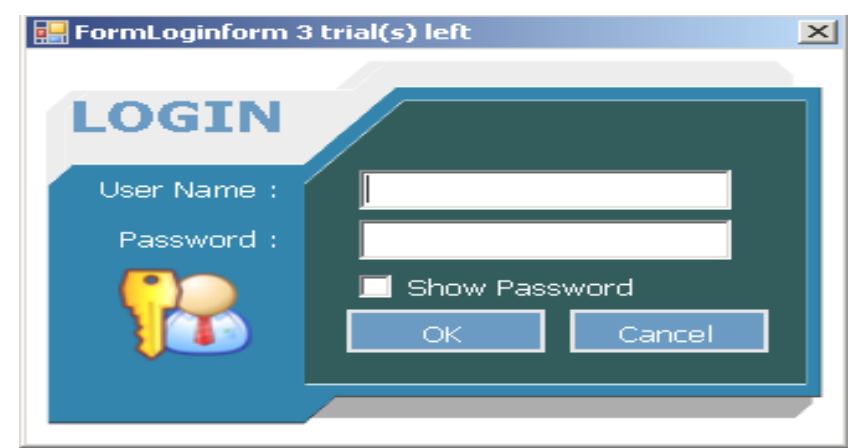

Gambar 3. 5 Halaman Login Sistem

Masukan User name dan password untuk bisa masuk ke Menu Utama Program (default) Username : admin, Password : admin

b. Menu Utama Program

Terdiri Dari : Menu Barang, Menu Supplier, Menu Pelanggan, Menu Pembelian, Menu Penjualan, Menu Hutang, Menu Piutang, Menu Kas (Cash Flow), Menu Laporan, Menu Back Office , Calculator dan Menu Pengaturan 


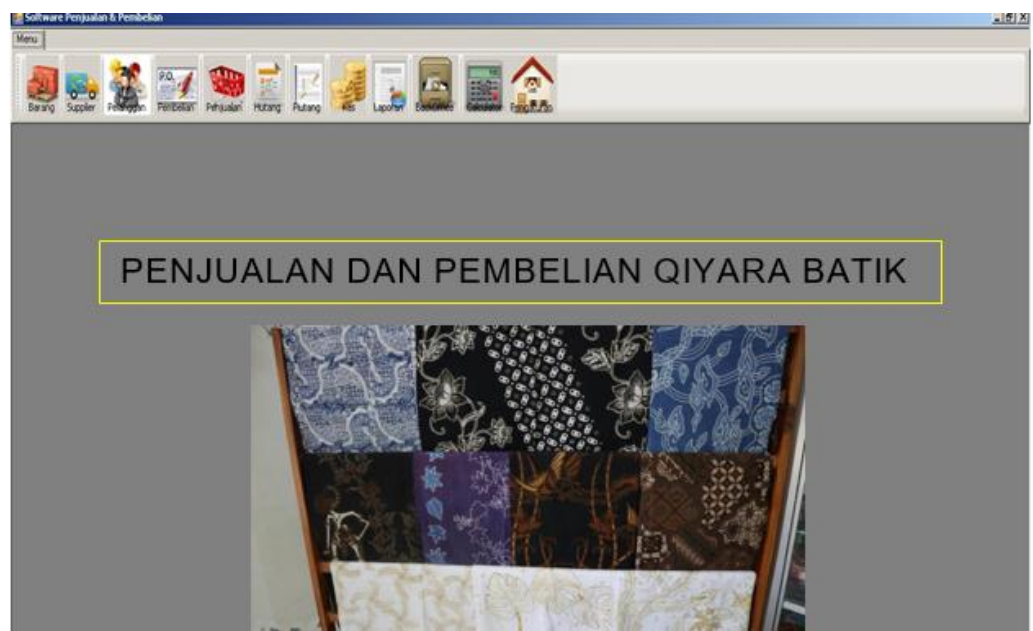

Gambar 3. 6 Halaman Menu Utama

c. Input Data Barang

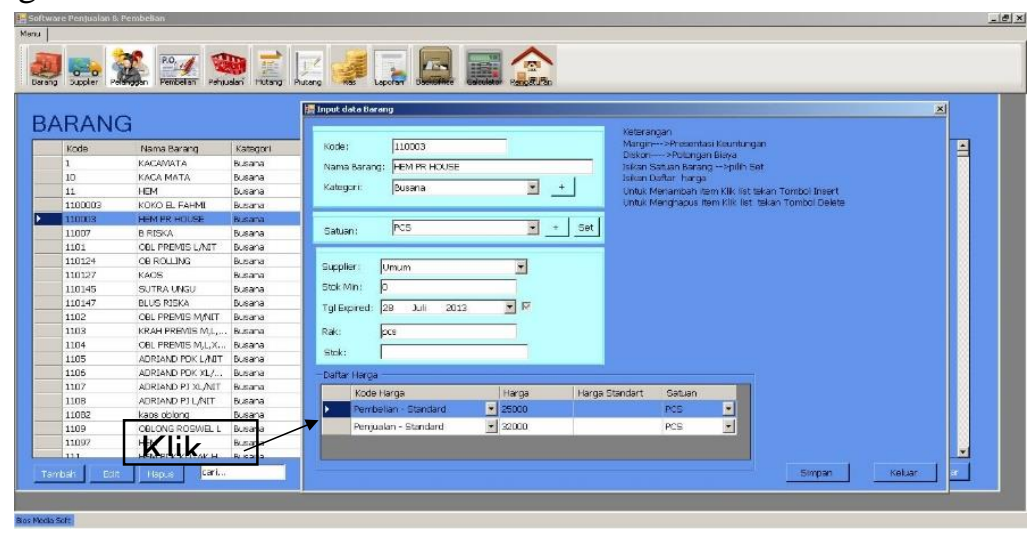

Gambar 3.7 Halaman Input Data Barang

Klik tombol tambah untuk mengisi input data barang baru, isi semua data untuk kategori baru klik tanda plus sebelah combo kategori, untuk satuan klik tanda plus combo sebelahnya, posisikan kursor pada kotak warna biru kecil kemudian klik insert untuk menentukan harga beli dan jual produk, kalau sudah di isi semua klik simpan

d. Input Data Pelanggan

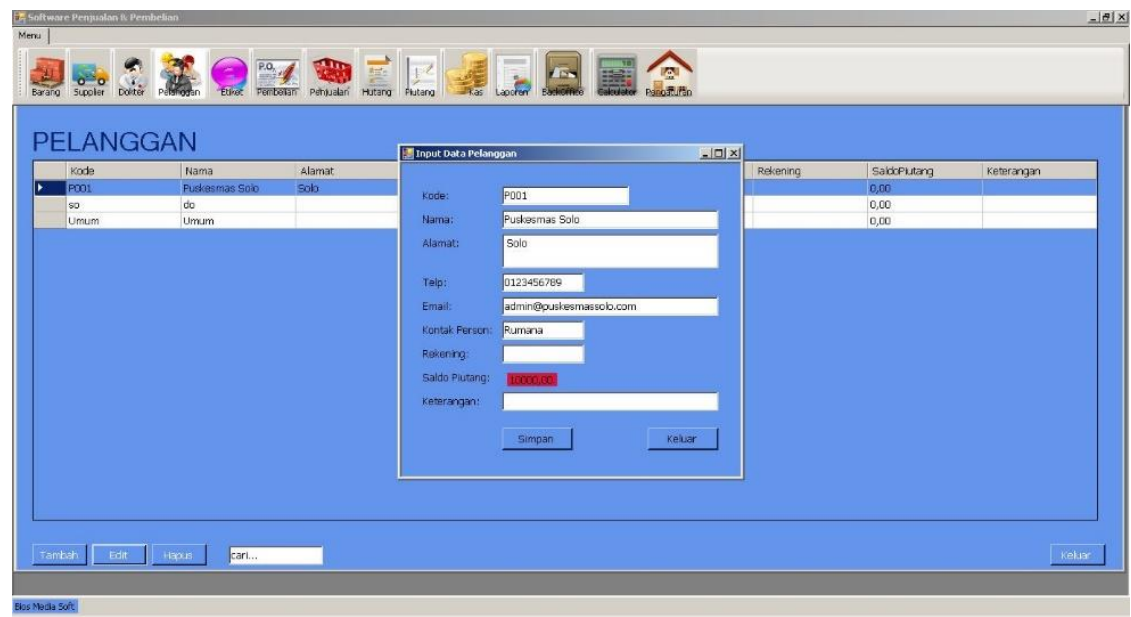

Gambar 3.8 Halaman Input Data Pelanggan

Klik tombol tambah untuk mengisi data pelanggan, disini ada saldo piutang yang nantinya jika pelanggan melakukan pembelian di toko kita secara kredit maka secara otomatis saldo piutang akan terisi sesuai piutang pelanggan ke kita. 


\section{SIMPULAN}

Berdasarkan hasil dan pembahasan kegiatan pengabdian kepada masyarakat dapat Hasil dari kegiatan pelatihan strategi digital marketing yang dilaksanakan secara teori dan praktik tentang platform media sosial seperti Fanspage, Instagram, dan marketplace yang ada saat ini seperti Shopee, Tokopedia, Lazada dapat berjalan dengan lancar sehingga peningkatan kemampuan pengetahuan teknologi informasi terhadap mitra, dan berdampak pada peningkatan omzet penjualan batik.

Dengan diterapkannya software Sistem Informasi Penjualan Qiyara Batik, maka dapat membantu dalam meningkatkan pelayanan terhadap pelanggan, dan mempermudah serta mempercepat pengelolaan administrasi transaksi penjualan sampai pengelolaan laporan-laporan.

\section{SARAN}

Kegiatan pengabdian kepada masyarakat melalui program hibah dari pemerintah maupun program pendanaan mandiri yang diselenggarakan oleh perguruan tinggi perlu dilakukan secara terus menerus dan ditingkatkan pendanaan hibah, dan sebagai perguruan tinggi khususnya para dosen sebaiknya terus mencari mitra UMKM yang membutuhkan pelatihan ini.

\section{UCAPAN TERIMA KASIH}

Dengan memanjatkan puji syukur kehadirat Allah SWT yang telah melimpahkan rahmat taufiq dan hidayahnya kepada kita sekalian, sehingga peneliti dapat menyelesaikan laporan ini dengan baik, dan tak lupa kami mengucapkan terimakasih kepada:

Direktorat Jendral Pendidikan Tinggi Riset, Dan Teknologi yang telah memberikan kesempatan kepada kami untuk melaksanakan Pengabdian Kepada Masyarakat Stimulus (PKMS) yang telah kami susun ini.

Ketua STMIK AUB beserta segenap jajarannya yang telah membantu proses pengajuan proposal PKMS sampai bisa lolos mendapatkan pendanaan dari Direktorat Jendral Pendidikan Tinggi Riset, Dan Teknologi.

Segenap rekan-rekan sejawat yang tidak bisa kami sebutkan satu persatu yang telah membantu memberikan motivasi serta dorongan sehingga bisa menyelesaikan kegiatan PKMS ini.

Penulis menyadari masih banyak kekurangan dalam menyusun laporan kemajuan PKMS ini, maka kami harapkan kritik dan saran yang membangun untuk meningkatkan kwalitas laporan ini.

\section{DAFTAR PUSTAKA}

Doni Agus Setiawan, (2020), "Sederet Permasalahan UMKM Selama Masa Pandemi Menurut Kemenkop

”, DDTCNews, Jakarta 26 Juni 2020 18:14, diakses 23 Oktober 2020

Sommerville, I.(2011)."Software Engineering”. ( $9^{\text {th }}$ Edition). United States : Pearson Higher Education. 